\title{
Molecular characterization of closteroviruses infecting Cordyline fruticosa L. in Hawaii
}

\author{
Michael J. Melzer*, Jari S. Sugano, Janice Y. Uchida, Wayne B. Borth, Michael K. Kawate and John S. Hu
}

Department of Plant and Environmental Protection Sciences, College of Tropical Agriculture and Human Resources, University of Hawaii, Honolulu, HI, USA

\author{
Edited by: \\ Giovanni P. Martelli, University of Bari \\ "Aldo Moro", Italy \\ Reviewed by: \\ Marc Fuchs, Cornell University, USA \\ Pasquale Saldarelli, Istituto di Virologia \\ Vegetale CNR, Italy \\ *Correspondence: \\ Michael J. Melzer, Department of \\ Plant and Environmental Protection \\ Sciences, College of Tropical \\ Agriculture and Human Resources, \\ University of Hawaii, 3190 Maile Way, \\ St. John 310, Honolulu, HI 96822, \\ USA. \\ e-mail: melzer@hawaii.edu \\ GenBank Accessions: JQ599282, \\ JQ599283, JQ599284
}

In Hawaii, common green ti plants (Cordyline fruticosa L.) have been shown to harbor Cordyline virus 1 (CoV-1) which, along with Little cherry virus 1 (LChV-1), and Grapevine leafroll-associated virus 7 (GLRaV-7), form a distinct clade within the family Closteroviridae. Preliminary work has indicated that, aside from CoV-1, three additional closteroviruses may infect common green ti plants in Hawaii. In this study, pyrosequencing was used to characterize the genomes of closteroviruses infecting a single common green ti plant. The sequence data confirmed the presence of CoV-1 as well as three additional closteroviruses. Although all four viruses had the same general genome organization, the sequence divergence between the RNA-dependent RNA polymerase, heat shock protein 70 homolog, and coat protein ranged from 22 to $61 \%$, indicating these represent four distinct closterovirus species. The names CoV-2, CoV-3, and CoV-4 are proposed for the three new viruses. Phylogenetic analyses placed CoV-2, CoV-3, and CoV-4 in the same clade as CoV-1, LChV-1, and GLRaV-7.

Keywords: pyrosequencing, Closteroviridae, Velarivirus, Cordyline, ti ringspot

\section{INTRODUCTION}

The family Closteroviridae represents a related group of mono- and multipartite, single-stranded, positive-sense RNA plant viruses with long, flexuous virions (Dolja et al., 1994). There are currently three genera in the family which are segregated largely based on vector species. Members of the genera Closterovirus, Crinivirus, and Ampelovirus are, in general, transmitted by aphids, whiteflies, and mealybugs, respectively (Karasev, 2000). Members of the genera Closterovirus and Ampelovirus have monopartite genomes, while members of the genus Crinivirus have multipartite genomes. Little cherry virus 1 (LChV-1) and Grapevine leafroll-associated virus 7 (GLRaV-7) are two members of the family that have not been assigned to a genus (Martelli et al., 2002). Molecular phylogenies and sequence similarity values associate them most closely to members of the genus Crinivirus, however, their monopartite genomes and their lack of a known insect vector have precluded their inclusion into this genus.

The ti plant, Cordyline fruticosa (L.), belongs to the plant family Agavaceae and has considerable cultural and economic importance in Hawaii and throughout most of Polynesia. In Hawaii, the common green variety was introduced by early Polynesian settlers and is a popular ornamental in residential settings that has also become naturalized in Hawaii's forests. Vegetatively propagated due to sterility (Hinkle, 2007), it is also the most prominent variety grown commercially. In 2009, ti farmers on the island of Oahu reported ringspot symptoms on their common green ti plants. These ringspot symptoms were subsequently observed on commercial and residential ti plants on the islands of Maui and Hawaii. In a search for a causal agent of the ringspot symptoms, it was recently discovered that Hawaiian ti plants harbored multiple putative members of the plant virus family Closteroviridae (Melzer et al., 2011). The complete nucleotide sequence for one of these viruses, Cordyline virus $1(\mathrm{CoV}-1)$, was determined. Its $16.9 \mathrm{~kb}$ genome was organized similar to LChV-1 and GLRaV-7 (Melzer et al., 2011). Together, LChV-1, GLRaV-7, and CoV-1 form a monophyletic clade distinct from the other three genera in the family Closteroviridae. This has led to proposals for the creation of a fourth genus, "Velarivirus," to represent these viruses (Al Rwahnih et al., 2012; Martelli et al., 2012).

A reverse-transcription polymerase chain reaction (PCR) assay revealed that CoV-1 is widespread in Hawaii and is present in ti plants with and without ringspot symptoms, making it unlikely to be involved in the etiology of the disease (Melzer et al., 2011). Based on partial sequence data, three additional closteroviruses were identified in ti plants. The objectives of this study are to further characterize these additional closteroviruses in common green ti plants and determine whether they represent distinct species (or strains of CoV-1) as well as their placement within the family Closteroviridae.

\section{MATERIALS AND METHODS LIBRARY SEQUENCING AND ASSEMBLY}

A previously described randomly primed complementary DNA (cDNA) library generated from double-stranded (ds) RNA isolated from a common green ti plant was used as the input material for multiplex pyrosequencing (Melzer et al., 2011). The most common cDNA length was estimated to be approximated $550 \mathrm{bp}$ based on agarose gel electrophoresis. MID7 (5'-ACGTACACACT- $3^{\prime}$ ) was ligated to the cDNAs which then underwent pyrosequencing using a 454 GS FLX Titanium platform (Roche, Branford, CT, USA) at the University of Hawaii's Advanced Studies in Genomics, Proteomics and Bioinformatics (ASGPB) laboratory. Following 
pyrosequencing, the MID7 and random primer sequences as well as low quality basecalls at the end of reads were trimmed. Short length ( $<65 \mathrm{nt})$ and low quality reads as well as those that mapped to the CoV-1 genome were purged from the dataset. The remaining reads underwent de novo assembly using Geneious ${ }^{\circledR}$ Pro 5.6.5 (Biomatters Ltd., Auckland, New Zealand). To validate low coverage regions or where unexpected stop codons or frameshifts occurred, and to bridge sequence gaps between contiguous sequences (contigs), primers were designed flanking the region in question and PCR was performed using the cDNA library as template. PCR products were either directly sequenced following treatment with ExoSAP-IT ${ }^{\circledR}$ (USB/Affymetrix, Santa Clara, CA, USA) or ligated into pGEM ${ }^{\circledR}-$ T Easy (Promega, Madison, WI, USA) followed by Sanger-based sequencing at the ASGPB.

The $3^{\prime}$-terminal sequences were obtained by polyadenylating heat-denatured dsRNA using yeast poly(A) polymerase (USB/Affymetrix) following the manufacturer's instructions. An oligo $d(T)$ primer [5'-CACTCCCTATTATCCAGG $\left.(\mathrm{T})_{16}-3^{\prime}\right]$ was used to initiate cDNA synthesis and also used in the subsequent PCR reaction along with a virus-specific primer designed to anneal near the $3^{\prime}$-end of the available virus sequence. Amplification products were cloned using $\mathrm{PGEM}^{\circledR}$-T Easy and at least five clones underwent Sanger-based sequencing at the ASGPB.

\section{PHYLOGENETIC ANALYSES}

The combined helicase domain (HEL), RNA-dependent RNA polymerase (RdRp), heat shock protein 70 homolog (HSP70h), p61 (PF03225), and coat protein (CP) amino acid sequences of members and tentative members of the family Closteroviridae were aligned using ClustalX 2.0.12 (Larkin et al., 2007). With this alignment, the phylogenetic relationships of the sequences were inferred using neighbor-joining (NJ) and maximum likelihood (ML) algorithms. The NJ algorithm was performed using ClustalX 2.0.12 and bootstrapped with 1000 replications. The ML algorithm was performed with PhyML 3.0 (Guindon et al., 2010) using the WAG model and bootstrapped with 1000 replications.

\section{RESULTS}

\section{LIBRARY SEOUENCING AND ASSEMBLY}

A total of 107,655 high quality reads $>64$ nt were generated from the cDNA library, with maximum, minimum, and mean lengths of 772, 65, and $392.1 \mathrm{nt}$, respectively. Of these reads, 4,424 mapped to the CoV-1 genome. The majority of the remaining reads assembled into three contigs, each in excess of $10 \mathrm{~kb}$ in length (Table 1). Based on comparisons with accessions in GenBank, all three contigs represented closterovirus-based genomes. The first contig was found to be essentially identical to the previously identified Contig5 (Melzer et al., 2011) where the two sequences overlapped, and was thus designated Contig5. Similarly, the second and third contigs were found to be essentially identical in overlapping regions with Contig8 and CloneH11, respectively, and were designated as such. The 15,031 nt Contig5 was extended to $15,107 \mathrm{nt}$ following the addition of the $3^{\prime}$-terminal sequence. The 14,941 nt Contig8 was extended to $16,274 \mathrm{nt}$ following the addition of the $3^{\prime}$-terminal sequence and a contig in the $5^{\prime}$-region of the genome. The 10,684 nt CloneH11 was extended to 14,620 nt with the addition of the $3^{\prime}$-terminal sequence and a contig in the $5^{\prime}$-region of
Table 1 | Summary of pyrosequencing results and assembly of reads into contiguous sequences (contigs).

\begin{tabular}{llll}
\hline & $\begin{array}{l}\text { \# of reads } \\
\text { (\% of total) }\end{array}$ & Length of contig & Mean coverage \\
\hline CoV-1 & $4,424(4.1)$ & $n / a$ & $n / a$ \\
CoV-2 (Contig5) & $11,395(10.6)$ & 15,031 & 342.8 \\
CoV-3 (Contig8) & $79,593(73.9)$ & 14,941 & 2410.8 \\
CoV-4 (CloneH11) & $3,537(3.3)$ & 10,684 & 168.7 \\
Unincorporated & $8,728(8.1)$ & $n / a$ & $n / a$ \\
\hline
\end{tabular}

1 Post-editing.

the genome. The $5^{\prime}$-terminal sequences were not obtained for any of the contigs.

\section{GENOME ORGANIZATION}

The overall genome organization of Contig5, Contig8, and CloneH11 were similar to that of CoV-1 (Figure 1), GLRaV-7, and LChV-1 (Jelkmann et al., 1997, 2012; Melzer et al., 2011). Although incomplete at their $5^{\prime}$-terminal regions, open reading frame (ORF) 1a of Contig5, Contig8, and CloneH11 encoded a polyprotein containing protease (PRO; PF05533), methyltransferase (MTR; PF01160), and HEL (PF01443) domains. ORF1a of Contig 5 and Contig8 terminated with the sequence $5^{\prime}$-UUUGA- $3^{\prime}$ with the stop codon underlined. This is also the terminal sequence of CoV-1 and GLRaV-7 (Melzer et al., 2011; Jelkmann et al., 2012) and may initiate $\mathrm{a}+1$ ribosomal frameshift allowing expression of ORF1b. ORF1a of CloneH11 terminated with the sequence $5^{\prime}$ UUUAA- $3^{\prime}$ that may also allow expression of ORF1b via the same frameshift mechanism. For all contigs, however, a start codon was present near the ORF1a termination sequence in the same reading frame of ORF1b that may also allow its expression. This was also observed for CoV-1 and LChV-1 (Jelkmann et al., 1997; Melzer et al., 2011). ORF1b of all three contigs encoded all the typical motifs of an RdRp (Koonin, 1991). Small transmembrane proteins 4 and $7 \mathrm{kDa}$ in weight were present between ORF1b and the HSP70h ORF for Contig5 and Contig8, respectively. No such protein was present at this location in CloneH11, however, a $4 \mathrm{kDa}$ protein with transmembrane properties was present in the +1 reading frame within C-terminal region of the HSP70h ORF (which is in the +3 reading frame). For all contigs, downstream of the HSP70h ORF was a 9-10 kDa ORF that is also present in CoV-1 and GLRaV-7, followed by ORFs encoding a 60-61 kDa protein common to all closteroviruses (PF03225), the major CP (PF01785), and then the minor CP (CPm). An ORF encoding a 25$26 \mathrm{kDa}$ homolog of CoV-1 p26 was present in Contig5, Contig8, and CloneH11. The final ORFs encoded by Contig5, Contig8, and CloneH11 were 28-29 kDa proteins. While p29 of Contig5 and p28 of Contig8 shared sequence homology with p29 of CoV-1, p29 of CloneH11 did not appear to be a homolog of these putative proteins, and did not have significant sequence similarity with any viral sequences currently in GenBank. The 3'-untranslated regions (UTRs) of Contig5, Contig8, and CloneH11 were 259, 154, and $186 \mathrm{nt}$, respectively. The exact $3^{\prime}$-termini of Contig5 and 


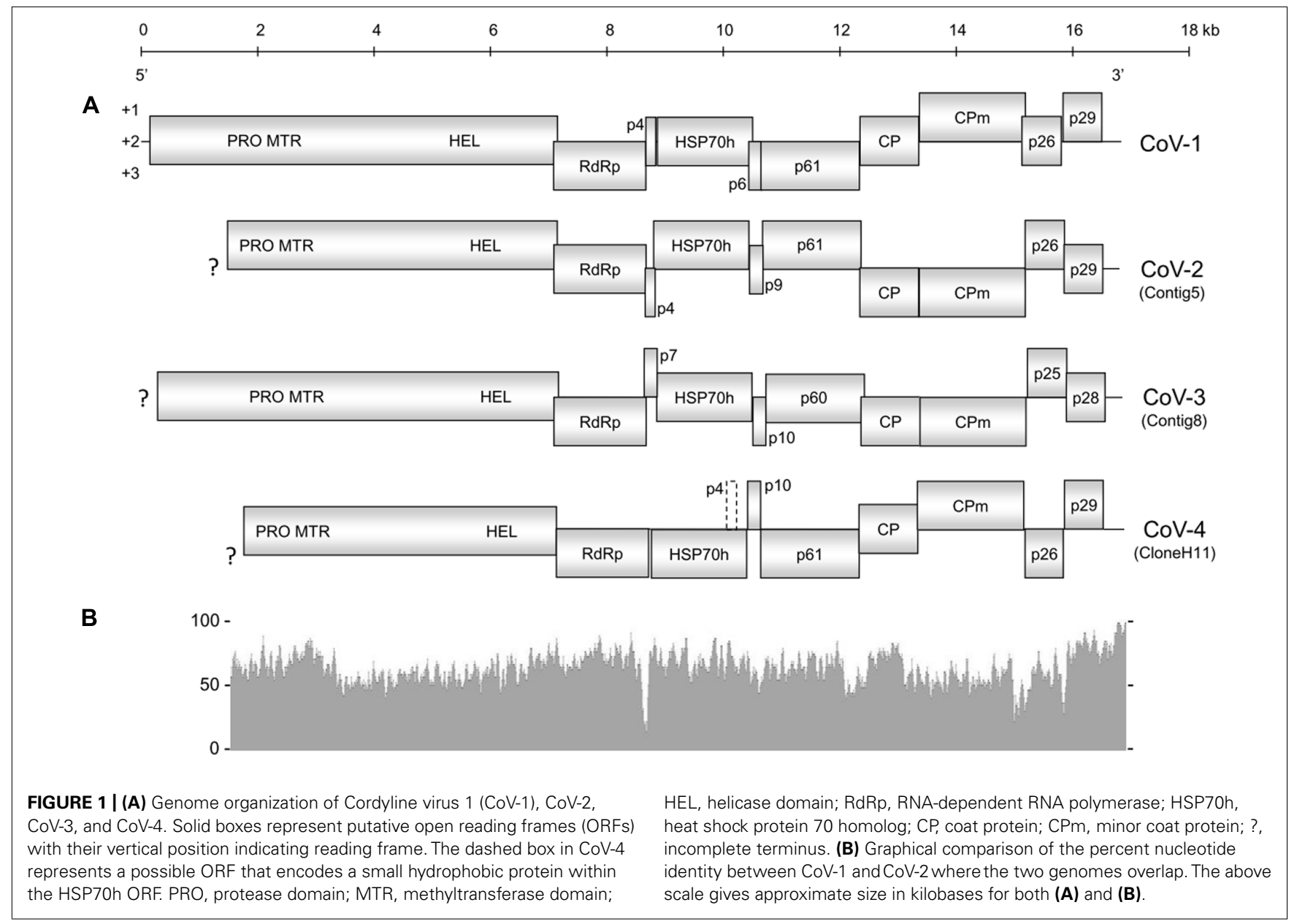

CloneH11 were identical to that of $\mathrm{CoV}-1$, having the sequence $5^{\prime}$...AAAGGUGCG-3'. Contig8 also ended with this sequence, but appeared to lack the terminal guanine residue.

\section{DIVERSITY AND PHYLOGENETIC PLACEMENT}

The amino acid identity between Contig5, Contig8, CloneH11, and CoV-1 for their respective RdRp, HSP70h, and CP sequences was under $70 \%$ in all cases except for the RdRp sequences of Contig5 and CoV-1 which were $78 \%$ identical (Table 2). Using the current criteria for closterovirus species demarcation recently revised by the International Committee on Taxonomy of Viruses (Martelli et al., 2011), these contigs would represent distinct closterovirus species. As such, Contig5, Contig8, and CloneH11 were tentatively designated $\mathrm{CoV}-2, \mathrm{CoV}-3$, and $\mathrm{CoV}-4$, respectively.

Cordyline virus 1 and CoV-2 appear to be the most closely related of the CoVs characterized in this study with an overall nucleotide identity of $63.7 \%$. Toward the $3^{\prime}$-termini of their genomes, however, the similarity gradually increased. This similarity peaked in the $3^{\prime} \mathrm{UTR}$ of $\mathrm{CoV}-1$ and $\mathrm{CoV}-2$ which shared a $90.8 \%$ nucleotide identity.

Over $8 \%$ of the total sequence reads did not map to the genomes of $\mathrm{CoV}-1, \mathrm{CoV}-2, \mathrm{CoV}-3$, or CoV-4 (Table 1). The majority of these appeared to be either of plant or prokaryotic origin, or did not share significant similarity to any of the sequence accessions in the current databases. Approximately $31 \%$ of these reads, however, represented closterovirus sequences. One thousand and ninetyfive of these reads were selected for further investigation. One hundred and seventy-four of these reads, when translated to amino acid sequences, were similar to the N-terminal region of a closterovirus ORF1a. Reverse-transcription PCR revealed this region was part of $\mathrm{CoV}-4$. The remaining reads, when translated to amino acid sequence, had high similarity (between 80 and $92 \%$ identity) to proteins encoded by $\mathrm{CoV}-1$.

Phylogenetic analyses of the combined HEL domain, RdRp, HSP70h, p60/61, and CP amino acid sequences using distance-based (NJ) and character-based (ML) algorithms inferred almost identical relationships between CoV-2, CoV-3, and CoV-4

\section{Table 2 | RNA-dependent RNA polymerase/heat shock protein 70 homolog/coat protein amino acid percent identities between the CoVs infecting common green ti plants.}

\begin{tabular}{llll}
\hline & CoV-1 & CoV-2 (Contig5) & CoV-3 (Contig8) \\
\hline CoV-2 (Contig5) & $78 / 69 / 67$ & & \\
CoV-3 (Contig8) & $62 / 50 / 44$ & $62 / 51 / 41$ & \\
CoV-4 (CloneH11) & $59 / 53 / 39$ & $57 / 51 / 40$ & $55 / 55 / 39$
\end{tabular}


and members of the family Closteroviridae. Both analyses clearly placed these four viruses along with CoV-1, GLRaV-7, and LChV-1 in a distinct clade within the family (Figure 2; data not shown).

\section{DISCUSSION}

We have previously reported the presence of one closterovirus, $\mathrm{CoV}-1$, infecting common green ti plants in Hawaii, and provided preliminary evidence for the presence of additional closterovirus species using a Sanger-based sequencing approach (Melzer et al., 2011). In this study we used a massively parallel sequencing approach to identify, in addition to $\mathrm{CoV}-1$, three new closterovirus species which we have tentatively designated $\mathrm{CoV}-2, \mathrm{CoV}-3$, and CoV-4.

Cordyline virus 2 and $\mathrm{CoV}-3$ share the same general genome organization as CoV-1, and differ from each other only in the molecular weight of their small hydrophobic proteins and the small protein encoded by the ORF located between their HSP70h and p61 ORFs. CoV-4, however, is unusual by lacking an ORF encoding a small transmembrane protein between the ORFs of the RdRp and HSP70h. The small transmembrane protein of Beet yellows virus (BYV) associates with the host endoplasmic reticulum and is involved in the cell-to-cell movement of BYV and presumably other closteroviruses as well (Peremyslov et al., 2004). An ORF which could encode a small protein possessing a transmembrane domain does exist in CoV-4, although it is located within the HSP70h ORF in a +1 reading frame relative to the HSP70h ORF. If this ORF is not expressed, it is possible that CoV4 requires co-infection with another closterovirus for cell-to-cell movement. Since all four CoVs were present in a single host plant, multiple infections in a single host plant may not be uncommon.

Overall, the genomes of CoV-1 and CoV-2 had a moderate sequence similarity. Near the $3^{\prime}$-terminus, however, this similarity gradually increased to the point where the $3^{\prime}$ UTRs of these viruses were nearly identical, indicative of a potential recombination

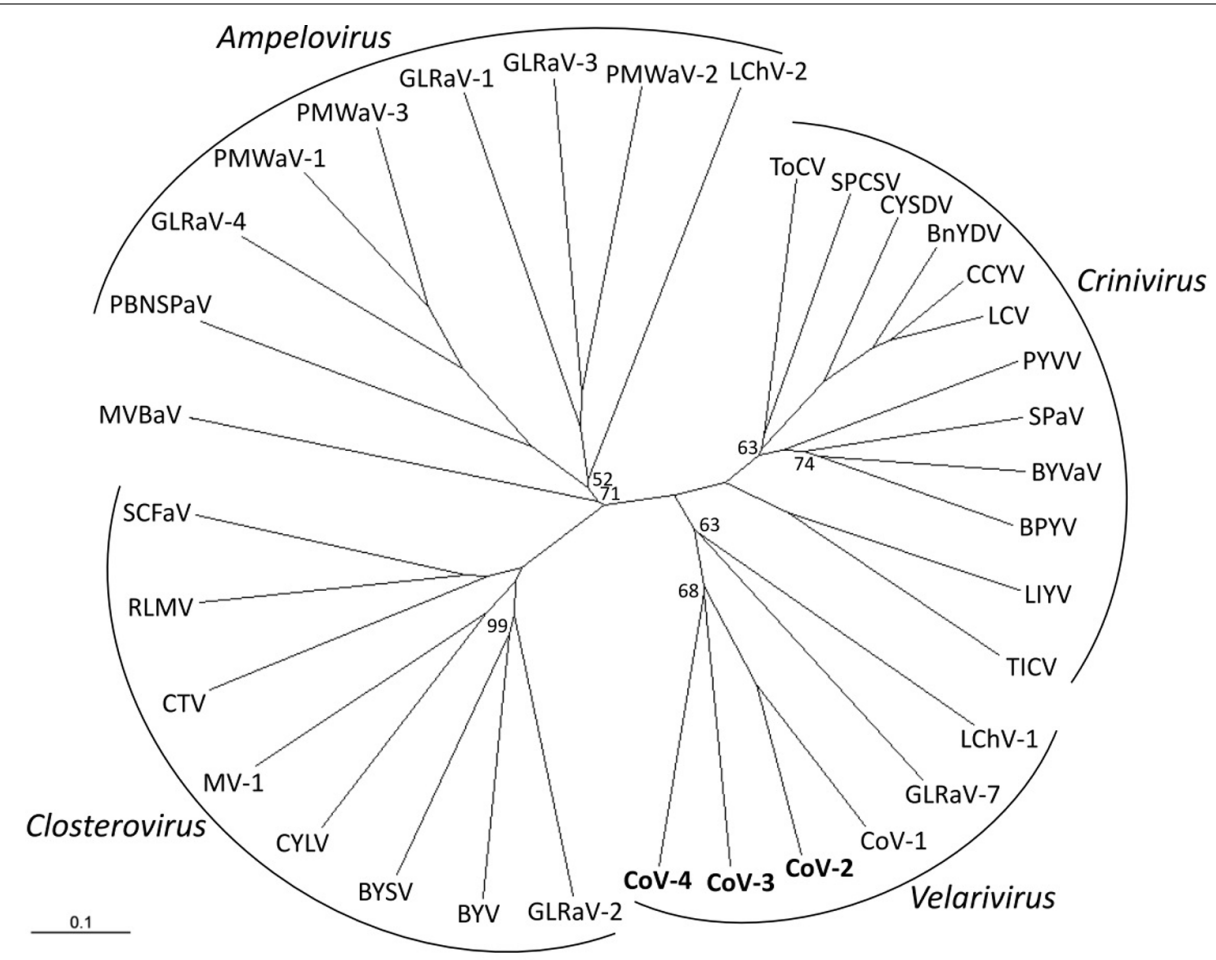

FIGURE 2 | Phylogenetic placement of Cordyline virus 2 (CoV-2), CoV-3, and CoV-4 within the family Closteroviridae using the combined RNA-dependent RNA polymerase, heat shock protein 70 homolog, p60, and coat protein amino acid sequences with a neighbor-joining algorithm and $\mathbf{1 0 0 0}$ bootstrap replications. Branch support is indicated in percentage support, and is $100 \%$ unless indicated, and the scale provides branch distance for the given number of substitutions. Virus abbreviations (GenBank accession numbers) are: Genus Ampelovirus: GLRaV-1, Grapevine leafroll associated virus 1 (AF195822); GLRaV-3 (NC_004667); GLRaV-4 (NC_016416); LChV-2 (AF416335); PBNSPaV, Plum bark necrosis stem pitting associated virus (YP_001552326); PMWaV-1, Pineapple mealybug wilt associated virus 1 (AF414119); PMWaV-2 (AF283103); PMWaV-3 (DQ399259); Genus Closterovirus: BYSV, Beet yellow stunt virus (U51931); BYV, Beet yellows virus (AF190581); CTV, Citrus tristeza virus (NC_001661); CYLV, Carrot yellow leaf virus (NC_013007); GLRaV-2 (AF039204); MV-1, Mint virus-1 (NC_006944); RLMV, Raspberry leaf mottle virus (NC_008585); SCFaV,
Strawberry chlorotic fleck-associated virus (DQ860839); Genus Crinivirus: BnYDV, Bean yellow disorder virus (NC_010560/NC_010561); BPYV, Beet pseudoyellows virus (NC_005209/NC_005210); BYVaV, Blackberry yellow vein-associated virus (NC_006962/NC_006963); CCYV, Cucurbit chlorotic yellows virus (AB523788/AB523789); CYSDV, Cucurbit yellow stunting disorder virus (NC_004809/NC_004810); LCV, Lettuce chlorosis virus (NC_012909/NC_012910); LIYV, Lettuce infectious yellows virus (NC_003617/NC_003618); PYVV, Potato yellow vein virus (NC_006062/NC_006063), SPaV, Strawberry pallidosis-associated virus (NC_005895/NC_005896); SPCSV, Sweet potato chlorotic stunt virus (NC_004123/NC_004124); TICV, Tomato infectious chlorosis virus (NC_013258/NC_013259); ToCV, Tomato chlorosis virus (NC_007340/NC_007341); Genus "Velarivirus" (proposed): CoV-1 (HM588723); CoV-2 (JQ599282); CoV-3 (JQ59983); CoV-4 (JQ599284); LChV-1, Little cherry virus 1 (NC_001836); GLRaV-7 (NC_016436); unassigned: MVBaV, Mint vein banding associated virus (AY548173). 
event. Putative examples of closterovirus recombination are abundant (Cuellar et al., 2008; Melzer et al., 2010; Farooq et al., 2013). The gradual increase in sequence similarity is comparable to that proposed for Citrus tristeza virus (CTV) strain T36, and suggests the potential recombination event was not recent (Mawassi et al., 1996). The presence of multiple CoVs in a single host plant would provide an environment conducive for such recombination events.

The family Closteroviridae Subcommittee to the International Committee on Taxonomy of Viruses (ICTV) has recently amended a commonly used criterion for species demarcation of closteroviruses. To be considered a distinct species, the level of sequence divergence in a phylogenetically informative protein (RdRp, HSP70h, or CP) was raised from 10 to $25 \%$ (Martelli etal., 2011). This increase in stringency was undertaken to address the proliferation of closteroviruses that had a similar genome organization, host range, and biological properties but, in some cases, only marginally exceeded the previous $10 \%$ sequence divergence criterion, thereby elevating them to species status (Martelli et al., 2012). Following the implementation of this more stringent criterion, a group of seven GLRaVs species and their "variants" (GLRaV-4, GLRaV-5, GLRaV-6, GLRaV$6 \mathrm{DE}, \mathrm{GLRaV}-9$, GLRaV-Car, and GLRaV-Pr) were condensed into a single species, GLRaV-4 (Martelli etal., 2012). Based on the amino acid identities of the RdRp, HSP70h, and CP sequences it is clear that $\mathrm{CoV}-1, \mathrm{CoV}-3$, and $\mathrm{CoV}-4$ are distinct species under the new criterion. The two most closely related $\mathrm{CoVs}, \mathrm{CoV}-1$ and $\mathrm{CoV}-2$, have amino acid divergence values for the RdRp, HSP70h, and CP of 22, 31, and 33\%, respectively. Although the sequence divergence between the CoV-1 and CoV-2 RdRp does not exceed the $25 \%$ threshold, the average sequence divergence for these three phylogenetically informative proteins is $29 \%$, and we therefore contend that CoV- 1

\section{REFERENCES}

Al Rwahnih, M., Dolja, V. V., Daubert, S., Koonin, E. V., and Rowhani, A. (2012). Genomic and biological analysis of Grapevine leafrollassociated virus 7 reveals a possible new genus within the family Closteroviridae. Virus Res. 163, 302-309.

Cuellar, W. J., Tairo, F., Kreuze, J. F., and Valkonen, J. P. T. (2008) Analysis of gene content in sweet potato chlorotic stunt virus RNA1 reveals the presence of the $\mathrm{p} 22 \mathrm{RNA}$ silencing suppressor in only a few isolates: implication for viral evolution and synergism. J. Gen. Virol. 89, 573-582.

Dolja, V. V., Karasev, A. V., and Koonin, E. V. (1994). Molecular biology and evolution of closteroviruses: sophisticated build-up of large RNA genomes. Annu. Rev. Phytopathol.32, 261-285.

Farooq, A. B. U., Ma, Y. X., Wang, Z., Zhuo, N., Wenxing, X., Wang, G. P., et al. (2013). Genetic diversity analyses reveal novel recombination events

and CoV-2 should represent two distinct species. Additional closterovirus-like sequences were also identified in the library. The majority of these, when translated into amino acid sequences, were only $10-20 \%$ divergent from CoV- 1 and are likely to have come from a second strain of CoV-1 that also infects common green ti.

The discovery of four related closterovirus species co-infecting the same host which share a similar genome organization and perhaps similar biological properties presents a situation reminiscent to the GLRaV-4 group. Since these four CoVs were discovered through the intense study of a single ti plant, it is also plausible that additional $\mathrm{CoV}$ species exist. Some members of the GLRaV-4 group, however, were found to be serologically related (Ghanem-Sabanadzovic et al., 2012). There are currently no antisera raised against any of the CoVs that would allow experiments to be conducted to determine their serological relationships. Given the amount of sequence divergence between the currently known CoVs, particularly in their respective structural proteins, it seems unlikely that they will be serologically related.

Within the family Closteroviridae, LChV-1, GLRaV-7, and $\mathrm{CoV}-1$ form a distinct monophyletic clade for which the genus "Velarivirus" has been proposed (Al Rwahnih et al., 2012; Martelli et al., 2012). Phylogenetic analyses placed CoV-2, CoV-3, and CoV4 within this clade. We therefore propose that $\mathrm{CoV}-2, \mathrm{CoV}-3$, and $\mathrm{CoV}-4$ also be members of the proposed genus "Velarivirus," should it be ratified by the ICTV.

\section{ACKNOWLEGMENTS}

The authors would like to thank Julie Coughlin, Dr. Shaobin Hou, Kenneth Hu, Chris Kadooka, James Kam, and Christina Liu for their assistance with this project. This project was supported, in part, by Award \#59955 from the Hawaii Department of Agriculture.

closterovirus. J. Gen. Virol. 78, 2067-2071.

ine 3 in China. Virus Res. 171, 15-21. Ghanem-Sabanadzovic, N. A., Sabanadzovic, S., Gugerli, P., and Rowhani, A. (2012). Genome organization, serology and phylogeny of Grapevine leafroll associated viruses 4 and 6: taxonomic implications. Virus Res. 163, 120-128.

Guindon, S., Dufavard, J. F., Lefort, V., Anisimova, M., Hordijk, W., and Gascuel, O. (2010). New algorithms and methods to estimate maximumlikelihood phylogenies: assessing the performance of PhyML 3.0. Syst. Biol. $59,307-321$.

Hinkle, A. E. (2007). Population structure of Pacific Cordyline fruticosa (Laxmanniaceae) with implications for human settlement of Polynesia. Am. J. Bot. 94, 828-839.

Jelkmann, W., Fechtner, B., and Agranovsky, A. A. (1997). Complete genome structure and phylogenetic analysis of little cherry virus, a mealybug-transmissible
Jelkmann, W., Mikona, C., Turturo, C., Navarro, B., Rott, M. E., Menzel, W., et al. (2012). Molecular characterization and taxonomy of grapevine leafroll-associated virus 7. Arch. Virol. 157, 359-362.

Karasev, A. V. (2000). Genetic diversity and evolution of closteroviruses. Annu. Rev. Phytopathol. 38, 293-324.

Koonin, E. V. (1991). The phylogeny of RNA-dependent RNA polymerases of positive-strand RNA viruses. J. Gen. Virol. 72, 2197-2206.

Larkin, M. A., Blackshields, G., Brown, N. P., Chenna, R., McGettigan, P. A., McWilliam, H., et al. (2007). Clustal W and Clustal X version 2.0. Bioinformatics 23, 29472948.

Martelli, G. P., Abou GhanemSabanadzovic, N., Agranovsky, A. A., Al Rwahnih, M., Dolja, V. V., Dovas, C. I., et al. (2012). Taxonomic revision of the family Closteroviridae with special reference to the grapevine leafroll associated members of the genus Ampelovirus and the putative species unassigned to the family. $J$. Plant Pathol. 94, 7-19.

Martelli, G. P., Agranovsky, A. A., Bar-Joseph, M., Boscia, D., Candresse, T., Coutts, R. H. A., et al. (2002). The family Closteroviridae revised. Arch. Virol. 147, 20392044.

Martelli, G. P., Agranovsky, A. A., BarJoseph, M., Boscia, D., Candresse, T., Coutts, R. H. A., et al. (2011). "Family Closteroviridae," in Virus Taxonomy. Ninth Report of the International Committee on Taxonomy of Viruses. eds A. King, M. J. Adams, E. B. Carstens, and E. Lefkowitz (Amsterdam: Elsevier-Academic Press), 9871001.

Mawassi, M., Mietkiewska, E., Gofman, R., Yang, G., and Bar-Joseph, M. (1996). Unusual sequence relationships between two isolates of Citrus tristeza virus. J. Gen. Virol. 77, 2359-2364. 
Melzer, M. J., Borth, W. B., Sether, D. M., Ferreira, S., Gonsalves, D., and $\mathrm{Hu}$, J. S. (2010). Genetic diversity and evidence for recent modular recombination in Hawaiian Citrus tristeza virus. Virus Genes 40, 111-118.

Melzer, M. J., Sether, D. M., Borth, W. B., Mersino, E. F., and Hu, J. S. (2011). An assemblage of closteroviruses infecting Hawaiian ti (Cordyline fruticosa L.). Virus Genes 42, 254-260.
Peremyslov, V. V., Pan, Y. W., and Dolja, V. V. (2004). Movement protein of a closterovirus is a type III integral transmembrane protein localized to the endoplasmic reticulum. J. Virol. 78, 37043709.

Conflict of Interest Statement: The authors declare that the research was conducted in the absence of any commercial or financial relationships that could be construed as a potential conflict of interest.

Received: 31 December 2012; paper pending published: 25 January 2013; accepted: 15 February 2013; published online: 05 March 2013.

Citation: Melzer MJ, Sugano JS, Uchido $J Y$, Borth WB, Kawate $M K$ and $\mathrm{Hu}$ JS (2013) Molecular characterization of closteroviruses infecting Cordyline fruticosa L. in Hawaii. Front. Microbiol. 4:39. doi: 10.3389/fmicb.2013.00039
This article was submitted to Frontiers in Virology, a specialty of Frontiers in Microbiology.

Copyright (C) 2013 Melzer, Sugano, Uchida, Borth, Kawate and Hu. This is an open-access article distributed under the terms of the Creative Commons Attribution License, which permits use, distribution and reproduction in other forums, provided the original authors and source are credited and subject to any copyright notices concerning any thirdparty graphics etc. 